\title{
British Marxist Historians: An Appraisal
}

\author{
Antony Kalashnikov
}

\begin{abstract}
This paper examines several of the leading British Marxist historians of the twentieth century and the contribution made by these Marxist historians to the field of historiography. The differences and similarities in the arguments presented by key Marxist historians is examined and critically analysed throughout this paper to identify the role these historians within the field.
\end{abstract}

\section{Introduction:}

In the second half of the twentieth century, Marxism became firmly integrated into the Western academic tradition as a valid and powerful mode of analysis. In 1950's Great Britain, Marxism became particularly prevalent in the discipline of history. At least superficially, a group of historians was associated by their membership within the British Communist Party. Several critics, however, have argued that the British Marxist historians came to represent a school, of sorts, characterized by much more than paying homage to Marx and his historical materialism. Indeed, sociologist Harvey Kaye, in his book The British Marxist Historians, contends that they constitute a separate "theoretical tradition." Specifically, he argues, they share a common theoretical problematic, historical problematic, approach to historical study (i.e. a methodology of class struggle analysis), and a contribution to British political culture. ${ }^{1}$ Social theorist Perry Anderson, for his part, also groups these Marxist Historians together, albeit indirectly, in his more negative critique of them. Particularly, he argues against their theoretical underdevelopment and lack of strategy. This essay will appraise the two scholars' arguments for British Marxist historians' commonality, in particular looking at the Marxist historians Edward Thompson and Eric Hobsbawm. In doing so, I will explicate Kaye's and Anderson's arguments, illustrating their points with examples from Thompson's and Hobsbawm's work. The essay will then examine the limitations of the arguments, arguing that the so-called "British Marxist historians" label is an artificial generalization not attuned to the individual variations.

\section{Kaye on British Marxist Historians:}

In Kaye's designation of British Marxist historians as a separate "theoretical tradition", one of the most important commonalities is their shared theoretical problematic. Kaye specifically means their rejection of the crude economic determinism that has been so characteristic of the Marxist legacy particularly the dogmatic work that had come out of Eastern Europe. ${ }^{2}$ This may be understood in two senses. First; British Marxist historians dismiss the historicist notion of a teleological and discernible progress of society from a primitive economy, through slave-ownership, feudalism, and capitalism, to a socialist/communist utopian end. Secondly, British Marxist historians also reject the

\footnotetext{
${ }^{1}$ Harvey J. Kaye, British Marxist Historians: An Introductory Analysis. Cambridge: Polity Press, 1984), 3-7.

${ }^{2}$ Georg Iggers, Historiography in the Twentieth Century: From Scientific Objectivity to the Postmodern Challenge (Middletown: Wesleyan University Press, 2005), 80-1.
} 
base-superstructure model of social totality, in which culture/ ideology/ politics, etc. is merely epiphenomenal to economic forces/ relations. Thus, Kaye claims, the historians accept a form of economic determination, but not determinism. ${ }^{3}$

Kaye never qualifies this linguistic distinction directly, but it seems that he derives the particular notion from E. P. Thompson's work (it is noteworthy that Kaye's general schema of British Marxist historians is derived most apparently from Thompson). In his essay "Peculiarities of the English", Thompson explicitly rejects the base-superstructure metaphor, because it ignores "the human dimension [and] the agencies of human culture," and fails to provide an explanation of social change. ${ }^{4}$ He proposes instead a model whereby the social formation is contextualized by a concrete economic mode of production (determining its limits and exerting certain pressures). However, this does not negate the infinite possibilities inside the economic mode itself - these are the subject to human agency and form the core of human experience. ${ }^{5}$ Hobsbawm's theoretical problematic is not as overtly developed as Thompson's. Nevertheless, it also does not endorse economic determinism. For example, Hobsbawm's work Nations and Nationalism Since 1780 avoids the economic dimension almost entirely. At most, there is the weak claim that nationalism served a utilitarian function in the development of the capitalist state - a thesis hardly acceptable to the classical Marxist. $^{6}$

\section{Common Historical Problematic:}

According to Kaye, British Marxist historians' not only share a common theoretical problematic, but also a common historical problematic. The historians' primary objects of study are the "origins, development, and expansion of capitalism", but not in the narrow economic sense. ${ }^{7}$ Rather, the social and cultural aspects are also unpacked, and achieve pre-eminence in some studies. While this is a keen perception, Kaye's argument must also be qualified by an admitted Eurocentrism - the historians tend to focus on Britain and the continent and the processes which originated there.

Thompson's preeminent work - The Making of the English Working Class - deals with the rise of labour consciousness in a pre-industrial primitive-capitalist context. Indeed, it deals with hard economic questions surprising little for a Marxist analysis of class in the emergence of capitalist economy (it even be said that the work carries a slight culturalist bias). In a similar way, the three areas of Hobsbawm's work - labour history, investigations of archaic revolutions, and world history - all deal thematically with capitalism. Certain studies, such as Primitive Rebels, have even focused on popular culture at the expense of 'concrete' data.

\section{Common Approach to Historical Study:}

Closely linked to their historical problematic, argues Kaye, British Marxist historians have a common approach to historical study - the methodology of class-struggle analysis. This is radically distinct

\footnotetext{
${ }^{3}$ Kaye, British Marxist Historians, 4-5.

${ }^{4}$ E. P. Thompson, The Poverty of Theory and Other Essays (New York: Monthly Review Press, 1978$), 291$.

${ }^{5}$ Thompson, The Poverty of Theory and Other Essays, 291-2.

6 Eric Hobsbawm, Nations and Nationalism Since 1780: Programme, Myth, Reality (Cambridge: Cambridge University Press, 1990), 80-100.

${ }^{7}$ Kaye, The British Marxist Historians, 5.
} 
from a 'class analysis', whereby reified categories are imposed upon a social formation to generate explanations necessarily following from the approach itself. Class-struggle analysis, by contrast, is an approach which looks at history from below. Thus, it takes into account the way people viewed themselves, and gives meaning to their struggles, even if they are misdirected according to a crude 'class analysis' schema. This echoes the Annales school's rejection of the courte durée events of high politics in favour of a more grassroots, ethnohistorical approach. ${ }^{8}$

Thompsons approach follows this schema. He states that "class in itself is not a thing, it is a happening." In $M E W C$, he argues that modes of production (capitalism) produces conflict around certain issues. Put simplistically, people gradually begin to see the patterns of conflict, and become self-conscious of acting in group ways over them. This led to the people imagining themselves as one class. This thesis also leads Thomson to focus more on popular culture and on the individuals (how they see themselves). Thus, his work attempts to "rescue the poor stockinger, the Luddite cropper, the 'obsolete' hand-loom weaver, the 'utopian' artisan, and even the deluded follower of Joanna Southcott, from the enormous condescension of posterity." 10 Hobsbawm takes a very similar approach in Primitive Rebels, focusing on the ways in which individual historical agents resisted the transformative processes around them. They did not define themselves in class terms and were backward-looking, but the conflicts they engaged in were nevertheless class-struggles fought against the encroachment of capitalism into their traditional lives.

\section{Contribution to British Political Culture:}

The final factor unifying the British Marxist school of history, in Kaye's understanding, is its contribution of British political culture. For one thing, the historians "broaden the conception of class experience in historical studies"; class experience and relations, in turn, are always "political' in that they always involve domination and subordination, struggle and accommodation." "Thus, they provide evidence for a more nuanced understanding of politics in the past, which can provide ammunition for struggle against oppression in the present. British Marxist historians also reaffirm the agency of the historical subject. Specifically, they emphasize political agency in resistance and rebellion; and this, comments Kaye, was at a time when 'social order' in the ivory tower meant consensus or total domination. In such a way, they give political agency meaning beyond "apolitical hysteria, criminal activity, or deviance." 12

Thompson's work can be seen in this light. His generally inspirational, agency-affirming thesis illustrates the power and value of the individual political experience, regardless of its consequences in terms of macro-processes of history. In a similar way, Hobsbawm's Primitive Rebels carries the quintessential political 'message' that pre-socialist/ pre-labour resistance to capitalism was neither 'futile', nor a 'waste of efforts'. While the social movements may have ultimately failed or faded out, they did provide tangible benefits, however limited, to the agents who struggled. Moreover, primitive resistance to capitalism were 'studies' for later, more class-conscious labour struggles.

\footnotetext{
${ }^{8}$ Kaye, The British Marxist Historians, 225-6.

${ }^{9}$ Thompson, The Poverty of Theory and Other Essays, 295.

${ }^{10}$ E. P. Thompson, The Making of the English Working Class (Harmodsworth: Pelican Books, 1968), 13.

${ }^{11}$ Kaye, The British Marxist Historians, 228.

${ }^{12}$ Ibid, 229-30.
} 


\section{Anderson on British Marxist Historians:}

While Kayes' perception of the British Marxist school is almost wholly positive, Anderson's critiques of the historians counterbalance the exaltations. Attitudes aside, however, it can be argued that Anderson also considers British Marxist historians to be a unified school. This essay will make the methodological assumption that Anderson's particular critiques of Thompson (for personal and circumstantial reasons, Anderson's primary object) apply beyond him to the British Marxist school where they address general methodological pitfall echoed in others' works. Thus, in criticizing Thomson's work, Anderson claims that his mistakes "[reveal] something about the culture and politics of all of us on the Left."13

\section{Theoretical Underdevelopment:}

Anderson claims that there has been an overall underdevelopment of Marxist theorizing in Britain ("no coherent tradition of Marxist thought at all.") ${ }^{14}$ This has led historians, inadvertently, to fallingback onto an empiricist mode of analysis. Thus, erudite historians pile up evidence, but lack robust conceptual categories of analysis, in which empiricism can only take them so far. In such a way, Anderson rejects the Thompsonite abandoning of the base-superstructure model in favour of a flimsy humanist focus on "the people [in] themselves." 15 For, it can be argued that this humanism is suspended in thin air and is not ontologically connected to modes of production, economy, classes, etc.

This theoretical underdevelopment and consequent retreat into empiricism is, to a certain extent, a shared feature of Marxist historians. It leads Thompson, for example, into naively embracing a superficial, bourgeois understanding of law in his study Whigs and Hunters: The Origin of the Black Act. Indeed, Thompson buys into the idea that bourgeois law of the time of Walpole represented an improvement and an instance of social progress because of a) its doctrine of equality before the law, and following from this b) being a constraint on the actions the ruling elite. ${ }^{16}$ However, a wider and more theoretically based approach would transcend this naivety; structuralist Nicos Poulantzas, for example, points out that some of the most despotic regimes (such as Genghis Khan's) have been characterized by a practice of rigorous equality before the law. ${ }^{17}$ Likewise, it can perhaps be said that Hobsbawm lacks a clear theoretical grounding for his study Nations and Nationalism. The thesis - nations and nationalism are socially constructed, nebulous, and changing phenomena - is a weak and relatively shallow observation. Indeed, it is perhaps that only conclusion which can be 'given by the facts alone' with an empirical treatment (i.e. people's attitudes towards nationalism changed, therefore nationalism is an unstable, changing occurrence).

\section{Lack of Strategy:}

\footnotetext{
${ }^{13}$ Perry Anderson, "Socialism and Pseudo-Empiricism," New Left Review 35 (1966): 3.

${ }^{14}$ Ibid, 32.

${ }^{15}$ Ibid, 36.

${ }^{16}$ See "Consequences and Conclusions" chapter in E. P. Thompson, Whigs and Hunters: The Origin of the Black Act (New York: Pantheon Books, 1975), 219-69.

${ }^{17}$ Perry Anderson, Arguments Within English Marxism (London: Verso Books, 1980), 71.
} 
Anderson notes “the divorce between [Thompson's] intimacy and concord with the late 18th and early 19th centuries, and his distance and lack of touch with the second half of the 20th century.",18 Specifically, he is criticising the lack of a strategic element to the politics of Thompson's works. Thomson replaces this strategic element with rhetoric and moralism - abstractions such indignation at 'apathy of workers'. In effect, Anderson contrasts this to his and Tom Nairn's investigation of British history, which aimed to understand the crisis of the British left in the 1960's in the historical context of the working-class movement. However, the criticism applies not only to Thompson, but to "many socialists" of his generation, who followed an "impressionist, inspirational tradition" devoid of concrete strategy. ${ }^{19}$ In other words, British Marxist historians often fail to provide historical explanations of the present and reveal practical strategic headways for current problems.

On a basic level, the historians have tended to shy away from $20^{\text {th }}$ century history. Anderson's criticism is also a qualification of Kaye's argument of 'the contribution to British political culture.' Indeed, while British Marxist historians may affirm the agency of the historical subject, it is difficult to see how this translates into concrete implications for socialism in the present. Thompson's Making of the English Working Class fails to generate a specific idea which could help practically guide the working class movement (how could it, dropping off before the Industrial Revolution as it does). In much the same way, while Hobsbawm's Primitive Rebels carrying a political message, it does not go beyond the affirmation of the value of praxis, resistance, and rebellion against the status quo.

\section{Limitations:}

The obvious, but nevertheless important limitation of Kaye's and Anderson's arguments for British Marxist historians' unity is that grouping is artificiallyimposed. In other words, the commonalities are conceptualized inductively/ analytically, as opposed to the group of historians subscribing to an already institutionalized practice. Naturally, this means that British Marxist historians write, and theorists subsequently perceive trends and generalities in their works. It needn't be said that where there are generalizations, there exist exceptions. Notwithstanding their commonalities, therefore, individual historians will never be the same on all counts.

For the one thing, Thompson and Hobsbawm have a different relationship to Marx, which affects all the above generalizations. Thompson repudiates both the romanticism of the early Marx and the dry political economy of the late Marx, preferring the 'middle Marx' of the 1840's (it may be said that he seems to sit on two chairs at the same time). ${ }^{20}$ In discussing Kaye's argument for a common British Marxist theoretical problematic, I illustrated Hobsbawm's opposition to 'crude economic determinism" by his narrative in Nations and Nationalism. This, however, is not full picture of his work. While Hobsbawm never officially subscribed to the base/superstructure division, Perry Anderson has insightfully noted his passive endorsement of the general model. Indeed, in his Age of ... trilogy, "each volume begins with an account of the economic foundations of the period, then a narrative of its political conflicts (in the first two volumes, headed 'Developments'), followed by a panorama of social classes, and then a survey of the cultural and intellectual scene (headed 'Results')."21

\footnotetext{
18 Anderson, "Socialism and Pseudo-Empiricism," 34.

${ }^{19}$ Anderson, "Socialism and Pseudo-Empiricism," 38-9.

20 Thompson, Poverty of Theory and other Essays.

${ }^{21}$ Perry Anderson, "Confronting Defeat." London Review of Books 24 (2002): 11.
} 
Hobsbawm's peculiar case points to a further limitation - the lifetime work of an individual historian must not be seen as monolithic. In other words, while a historian may in general conform to Kaye's and Anderson's ideal-type, they nevertheless often experience an evolution/change in their work (indeed, much like Marx himself did). This can be seen from a number of angles. It would be difficult, for example, to see how Thompson's "Poverty of Theory" suffers from what Anderson calls 'theoretical underdevelopment', when he explicitly lays out the ideas which governed his previous scholarship. Likewise, while Kaye may argue for a characteristic 'history from the bottomup' British Marxist methodology, Hobsbawm's Nations and Nationalism since 1780, for example, stands in direct contrast to his Primitive Rebels. If anything, the former takes a top down approach, not only in its courte durée, high-politics focus, but also in its thesis of nationalism as 'imposed from above.' Ironically, while paying lip-service in saying that the phenomenon 'cannot be understood unless also analysed from below", Hobsbawm never does so in the study itself. ${ }^{22}$

Likewise, the generalization of a common political contribution (or, in Anderson's case, a lack of political strategy) is relative to the observer and the individual historian. If one is a communist looking at their party record, Thompson and others (e.g. Rodney Hilton, Christopher Hill, etc.) 'betrayed the cause' in 1956, unlike Hobsbawm who remained a lifelong member. ${ }^{23}$ On the other hand, if one looks at their political action as activism, Thompson far outstrips Hobsbawm's relative isolation by his involvement in the Antinuclear Movement and his prolific writing of political essays, articles, and brochures. ${ }^{24}$ Moreover, it remains to be shown how exactly their extracurricular involvement, shared or otherwise, applies to their work as historians of a common theoretical tradition. If one looks at the historical works themselves, a mere cursory glance would reveal that if there is indeed a commonality in their political contribution, it is in having one (but not in having a unified one). Indeed, on a certain level it is amusing to see the extent of bile and petty infighting that permeates their academic work. E. P. Thompson, for example, declares "unrelenting intellectual war" against Althusser in Poverty of Theory, taking up ad hominem derisive questions such as "where was Althusser in 1956?"25 Moreover, Thompson in general writes off "Western Leftist intelligentsia [as] distinguished by its lack of political experience and judgement." 26 Anderson himself commits a scathing review of Thompson's essay "Peculiarities of the English" (which was of a review of his and Nairn's work in the first place). While Hobsbawm has admittedly tried to stay out of these polemics, the point remains that British Marxists in no way represent a 'united political front.'

\section{Conclusion:}

In such a way, this essay has explicated Kaye's and Anderson's arguments for the commonality of British Marxist historians. Though the work of E. P. Thompson and Eric Hobsbawm provides numerous illustration for such an argument, it must always be noted be noted that Kaye's and Anderson's grouping is generalization of informal commonalities. As such, one should be attuned to the individual differences and exceptions in the work of British Marxist historians. With this

\footnotetext{
${ }^{22}$ Hobsbawm, Nations and Nationalism, 10.

${ }^{23}$ Kaye, The British Marxist Historians, 17.

24 See Anderson, Arguments Within English Marxism, 210-1, for list of Thompson's political writings.

${ }^{25}$ Thompson, Poverty of Theory and Other Essays, 165-92.

26 Thompson, Poverty of Theory and Other Essays, 184.
} 
qualification, it can nevertheless be agreed that the British Marxist school stands as an important monument in the $20^{\text {th }}$ century study of history. 


\section{Bibliography:}

Anderson, Perry. Arguments Within English Marxism. London: Verso Books, 1980.

-----. “Confronting Defeat.” London Review of Books 24 (2002): 10-15.

. "Socialism and Pseudo-Empiricism." New Left Review 35 (1966): 2-42.

------. “The Age of EJH.” London Review of Books 24 (2002): 3-7.

Hobsbawm, Eric. The Age of Capital: 1848-1875. London: Sphere Book Ltd., 1977.

------. Nations and Nationalism Since 1970: Programme, Myth, Reality. Cambridge: Cambridge University Press, 1990.

-----. Primitive Rebels: Studies in Archaic Forms of Social Movement in the $19^{\text {th }}$ and $20^{\text {th }}$ Centuries. New York: W. W. Norton \& Company, 1965.

Iggers, Georg. Historiography in the Twentieth Century: From Scientific Objectivity to the Postmodern Challenge. Middletown: Wesleyan University Press, 2005.

Kaye, Harvey J. The British Marxist Historians: An Introductory Analysis. Cambridge: Polity Press, 1984.

Thompson, E. P. “Eighteenth Century English Society: Class Struggle without a Class". Social History 3 (1978): 133-165.

-------. The Making of the English Working Class. Harmodsworth: Pelican Books, 1968.

------. The Poverty of Theory and Other Essays. New York: Monthly Review Press, 1978.

------. Whigs and Hunters: The Origin of the Black Act. New York: Pantheon Books, 1975. 